\title{
Against the Academic Brexit Industry: Brexit Troubles for the Social Sciences-and How to Cope with them
}

\author{
David Inglis* \\ Faculty of Social Sciences, University of Helsinki, Finland
}

Submission: October 09, 2017; Published: November 30, 2017

*Corresponding author: David Inglis, Faculty of Social Sciences, University of Helsinki, Helsinki 00170, Finland, Email: david.inglis@helsinki.fi

\section{Introduction}

It was clear right from the moment that the Brexit referendum results were announced on $24^{\text {th }}$ June 2016 that the ensuing consequences of UK withdrawal from the European Union would be a bonanza for academia, albeit in a peculiar way.

While in personal and political terms social science and humanities scholars in the UK and other countries may have been variously appalled, angry, bitter, shocked and traumatised, in professional terms many would already have been sizing up the opportunities being offered to them by this apparently momentous event.

Nothing is as productive of academic papers, books, journal special editions, conferences, debates, symposia, contributions to the media and so on, than those events that are billed as seismic shifts or social catastrophes. The clouds of disaster bring with them silver linings for those gearing up to study them, bringing as they do novel (and not so novel) objects of study, new phenomena to sharpen one's pen on, and possibly new sources of funding. If one can quickly reorient what one was doing any way to make it Brexit-relevant, then there are opportunities to be grasped, audiences to be reached, and careers to be generated.

And so it has proved. Brexit has been, and will continue to be for a long time, highly productive for academia. The list of publications and events about Brexit coming from the social sciences is already lengthy, and being added to day by day, week by week. Brexit has become, and will continue to be, a vast generating machine of social science, fed and fuelled by every sort of specialist, and attracting ever more people who bend and fit the sorts of things they were doing beforehand, to make them germane to Brexit. Intentions range across a wide spectrum, from feelings of professional obligation to bring to bear one's specialist know-how on Brexit matters, to sincere concern to contribute to a better understanding of Brexit phenomena, through to sheer opportunism and naked careerism, and not wanting to miss out on what apparently everyone else is talking about.
I noticed that throughout later 2016 and 2017 in the UK university system many social scientists were increasingly exhibiting forms of double consciousness, or multiple personalities. On the one hand, they were usually deeply unhappy about Brexit, especially its probable highly negative consequences on the universities. People were worried about the dire economic ramifications of Brexit, including the major loss of funding from EU sources and the possible collapse in numbers of EU students wishing to study in the UK.

Yet, on the other hand, people were, in often quite positive, rather than distraught, ways, gearing up to 'do Brexit'. Existing research plans were reworked so as to be Brexit-relevant. Plans for Brexit-themed books and articles were hatched. Professional affairs were being rapidly recalibrated in the direction of Brexit. The apparatuses of scholarship were rapidly being Brexitised.

One might see that as simply necessary realism-that's the way things are going in the world, so I will have to reflect that in what I study. If Brexit is the elementary social fact in and about the UK today, surely it would be very remiss not to engage with it? But in the last year and a half I detected more than that sentiment, in at least some quarters-namely, the desire to jump on the ever more loaded bandwagon and utilise Brexit for all it is worth, whatever that may be.

The more it has become unclear what Brexit will actually involve, the more murky and ambiguous the form Brexit and its consequences may take, the more productive of academic writing and researching Brexit has been and will be. The very ambiguity allows more and more scholars, of every size and shape, to claim Brexit-or rather, slivers of it, carved off it by specialist knowledge's-as their own. The term 'Brexit' can be bent and shaped any which way, so that the scholar who is working it can get the results that they require.

Already taking shape are hundreds, if not thousands, of scholarly Brexits-multiple political ones, and social ones, and economic ones, as well as cultural, technological, ethnic, class, 
gender, urban and rural ones, and so on and so forth. The list is potentially endless. There are as many Brexits as there are scholarly domains-and Brexit can bring new ones into existence too. In and through the construction of these multiple Brexits, claims are made about one's expertise to talk about Brexit and to claim ownership over it. And as that happens, turf wars break out between rival interpretations of the 'same' Brexit, and between different, rival conceptions, epistemologies and ontologies of Brexit

In Bourdieu's [1] terms, the scholarly field of Brexit is shaping up and taking form, and the dynamics will be particularly conflictual, because so many different actors, and types of actors, are joining the fray, and the field is becoming ever more crowded. But s/he who dominates, for a while at least, the symbolic means of constructing and representing Brexit-to academics, to politicians and policy-makers, to the media, and to diverse civilian publics-stands to gain much in terms of power and standing, within academia and without.

And if it is the case that academic constructions of Brexit can play roles in shaping what extra-academic groups think about what Brexit is and how it should be handled [2], then those who dominate in the defining of Brexit intellectually may well play a major role in the processes that play out in defining it politically. There is a lot at stake, and a lot to be gained, if an individual or a group can persuade influential others that one is a key Brexit expert-a Brexpert.

One infamous comment from the Referendum campaign now stands on its head. The Conservative politician and leading Leave campaigner Michael Gove stated that everyone (meaning confirmed and potential Leave voters) was now sick of hearing from 'experts'. Such experts, including academic ones, had the unfortunate habit of setting out data and arguments showing how disastrous a Leave result would be. Just like climate-change deniers have to trash climate science, so as to delegitimate its 'inconvenient truths', so too did the Leave campaign have to trash expertise, because most of it pointed in the wrong direction, towards Remain. Knowledge specialists of all varieties had to be painted as biased towards the EU, as part of the Establishment that was doing Britain down. Academics in particular were said to be EU-funding junkies, whose facts were no facts at all and whose arguments were pro-EU propaganda. It seemed for a brief period after the Referendum that experts and expertise had been seriously undermined by the rhetoric surrounding Brexit. But as it has turned out, Brexit now figures as a massive machine for producing more and more experts and expertise, all of which are seeking not just to understand it, but also to master and harness it, and call it their own and make it work for them. Brexit is a knowledge-producing generator par excellence. The academic Brexit industry will continue to grow and grow.

Clearly there are many dangers for the social sciences and humanities at this juncture. With such a massive pumping up of the field of studies of Brexit currently going on, there are likely going to be a lot of poor studies produced. The worst will be done for the purposes of career-generation rather than for more genuinely world-enhancing reasons. Scores of mediocre, or worse, articles, books, projects, discussions and $\mathrm{PhD}$ theses are already starting to be born out of the Brexit Hadron Collider. As Brexit becomes an obligatory topic in UK academia and further afield, it threatens to consume the individual disciplines, dragooning a generation into making compulsory reference to it, and producing Brexit-themed normal science by the bucket-load. Of course, some good, perhaps excellent, material will come out of all of this. But a lot of what is produced will be wastage, by dint of the hugeness of the coming Brexit industry and the obligatory nature of Brexit themes.

For disciplines like anthropology and sociology, the dangers are great, especially in the UK. They are under increasing governmental funding to be 'relevant' to the needs of the state and big business, so for them not to engage with Brexit would look like a shirking of their already fragile claims to relevance. Engagement with Brexit will not be a matter of choice but of compulsion.

The economic consequences of Brexit are also likely to reduce already shrinking research budgets further. So a peculiar situation will come into play whereby scholars seeking money to study Brexit will be forced into ever fiercer and more moralesapping competition with each other, precisely because what they want to study, Brexit, has undermined the very financial basis of what they do. Brexit takes away your livelihood at the same time as you are forced to study it, even if you do not want to study it. 'Brexit anthropology' and 'Brexit sociology' are therefore more than just the anthropology and sociology of Brexit. They are also institutional and intellectual formations which seek to grasp something, Brexit, which itself undermines the viability of the disciplines.

Given all this, it is clear that anthropology, sociology and other academic fields are going to have to negotiate the world thrown up by Brexit very gingerly indeed. They are forced to study it, but they must also try not to succumb to it. To that end, I propose a few rules for how scholars might play the 'Brexit game' over the next few years.

In their research, writing and intellectual practice generally, individuals, groups, whole disciplines and cross-disciplinary intellectual formations should:

a. RESIST regarding Brexit as an obligatory subject matter and reference point. If it can be ignored for good intellectual reasons, then ignore it, even if this comes at some sort of cost.

b. AVOID succumbing to the temptation to conjoin directly social science to whatever is in the Brexit-related headlines that week. 
c. Do not write the kind of analysis that is basically no deeper or insightful than Guardian journalism, but which has a lot of big words added to it to make it sound 'academic' and clever.

d. BAN yourself from using Brexit as any sort of opportunistic, career-advancing mechanism.

e. If you feel you genuinely have something important and novel to say about Brexit, say it. If you don't, then don't. Don't Brexitise your work for the purposes of CV-bulking, promotion, tenure, or aggravating your colleagues.

f. ENSURE that, if you do produce a Brexit-related publication or event, it involves people whose voices are less likely to be otherwise heard. Make sure your contribution is not stuffed full of your intellectual area's usual, ubiquitous talking-heads and media stars, who command all the airwaves in your scholarly world anyway. They are probably Brexit-ing for careerist reasons, and will have lots of other opportunities for grandstanding and claiming their rights to be the masters of Brexit talk.

If even some of us follow these basic rules-of-thumb at least sometimes, then possibly we all may eventually come out at the other side of the Brexit maelstrom not quite as messed up as we otherwise undoubtedly will be.

\section{References}

1. Bourdieu P (1990) Homo Academicus. Polity, Cambridge, USA.

2. Law J, Urry J (2004) Enacting the Social: Economy and Society 33(3): 390-410.

\section{Your next submission with Juniper Publishers will reach you the below assets}

- Quality Editorial service

- Swift Peer Review

- Reprints availability

- E-prints Service

- Manuscript Podcast for convenient understanding

- Global attainment for your research

- Manuscript accessibility in different formats

( Pdf, E-pub, Full Text, Audio)

- Unceasing customer service

Track the below URL for one-step submission https://juniperpublishers.com/online-submission.php 